\title{
Analysis of Brazilian livestock transformations: a focus on dairy farming
}

\section{Análise das transformações da pecuária brasileira: um enfoque na pecuária leiteira}

\author{
Rodrigo de Andrade Ferrazza ${ }^{1 *}\left([)\right.$, Elena Castellani ${ }^{1}$
}

${ }^{1}$ Universidade Estadual de Londrina (UEL), Londrina, Paraná, Brazil

*Correspondent: rodrigoferrazza@yahoo.com.br

Received

May 14, 2021.

Accepted

September, 14, 2021.

Published

November 10, de 2021.

www.revistas.ufg.br/vet visit the website to get the how to cite in the article page.

\begin{abstract}
In this study, we investigated the principal transformations in dairy farming among Brazilian federative units in the period from 2006 to 2017. Data were drawn from the Agricultural Censuses from 2006 and 2017. In order to compare the variations between the states and macroregions, descriptive analyses were performed. Pearson correlation was used to test the correlation among the variables. A 4.63\% decrease was observed in the number of establishments supporting cattle, notably in the states of PE (-23.02\%), RS (-20.67\%) and PR $(-19.65 \%)$. Some states showed greater participation in terms of increase in number of cattle, particularly in the Northern region. No significant change in pasture area was observed. A decrease of $12.92 \%$ in number of milk producers was observed, mainly in the traditional dairy basins, such as RS (-36.62\%), PR (-27.33\%), SP $(-24.67 \%)$ and SC (-20.21\%). Producers who continued in the activity had a rise in the scale of their daily production. Although there was a $9.47 \%$ reduction in the number of cows milked, the herd productivity showed a $61.96 \%$ surge, particularly in the Southern (72.98\%) and South-eastern (62.31\%) areas. Milk production revealed higher correlation with number of cows milked $(P<0.05 ; r=0.97)$ and productivity per cow $(P<0.05$; $r=0.63)$, than with area of the rural establishments $(P<0.05$; $r=0.38$ ). In conclusion, there were significant changes in dairy farming over an eleven-year period, including changes in the geography of production, greater concentration and professionalization of the activity, as well as the expressive growth of milk production in almost every state, which is reflective of higher productivity of the national herd.

Key words: Cattle; Agricultural Census; Federative unit.
\end{abstract}

\section{Resumo}

Objetivou-se com este estudo caracterizar as principais transformações ocorridas na pecuária leiteira entre as unidades federativas do Brasil no período de 2006 a 2017. Foram reunidos dados dos Censos Agropecuários de 2006 e 2017. Em seguida, foram feitas análises descritivas para comparação das 
variações entre estados e macrorregiões. Para testar o relacionamento das variáveis foi utilizado o teste de correlação de Pearson. Houve redução de 4,63\% no número de estabelecimentos com bovinos, com destaque para os estados de PE $(-23,02 \%)$, RS $(-20,67 \%)$ e PR (-19,65\%). Houve crescimento da participação de alguns estados no número de bovinos, especialmente da região Norte. A área de pastagem não mudou significativamente com o passar dos anos. Verificou-se redução de $12,92 \%$ no número de produtores de leite, principalmente em bacias leiteiras tradicionais, como RS (-36,62\%), PR (-27,33\%), SP $(-24,67 \%)$ e SC $(-20,21 \%)$. Os produtores que permaneceram na atividade aumentaram sua escala de produção diária. Embora houve decréscimo de 9,47\% no número de vacas ordenhadas, a produtividade do rebanho aumentou 61,96\%, com destaque para as regiões Sul (72,98\%) e Sudeste (62,31\%). A produção de leite foi mais correlacionada com o número de vacas ordenhadas $(P<0,05 ; r=0,97)$ e com a produtividade por vaca $(P<0,05 ; r=0,63)$, do que com a área dos estabelecimentos rurais ( $P<0,05 ; r=0,38)$. Conclui-se que mudanças importantes ocorreram na pecuária leiteira no intervalo de onze anos, incluindo mudanças na geografia da produção, maior concentração e profissionalização da atividade, além do expressivo crescimento da produção de leite em praticamente todos os estados, reflexo da maior produtividade do rebanho nacional.

Palavras-chave: Bovino; Censo Agropecuário; Unidade federativa.

\section{Introduction}

Agribusiness in Brazil, from an economic standpoint, is a vital activity that plays a significant role in providing employment and generating income, thus helping to maintain the trade balance. In agribusiness, raising cattle ranks high among the most critical pursuits. All the Brazilian states are involved in raising beef cattle, defined by a strong dependence on pastures, and ensuring that the zebu genotypes are predominant in the cattle herd ${ }^{(1)}$. Apart from this, dairy farming is also practiced across the national territory, with remarkable heterogeneity in the production techniques, herds and kinds of producers ${ }^{(2)}$. In the recent decades, huge and heterogeneous transformations have occurred in the livestock, in all the sectors, reflective of the technological advancements made in the production systems and organization of the production chain ${ }^{(3,4)}$. Despite these, Brazilian cattle raising continues to require enhancement, from the managerial and productivity angles, to ensure higher levels of competitiveness.

The Agricultural Census survey done periodically by the Brazilian Institute of Geography and Statistics (IBGE), and on a national scale, provides the general data regarding the agricultural establishments and their activities. Such data is fundamental to the characterization of the production systems, giving a clearer picture of the changes that 
had taken place over the decades ${ }^{(5,6)}$.

In light of the significance and specificity of the livestock activity, further research and deeper analyses are still required. In this setting, spatial analyses and inter-census comparisons of the livestock activity can provide crucial data that can help deepen the current knowledge of the characteristics and changes in the geography of production, besides enhancing one's understanding of the likely consequences of the livestock activity and the competitive environment that the country faces. Further, these results promote the formulation of public policies that can boost this sector and thus the regional economy.

Therefore, based on the official census data, we characterize the principal transformations that dairy farming has experienced in the various Brazilian federative units, during the 2006 to 2017 time period.

\section{Material and Methods}

\section{Data collection}

Data from the $2006^{(7)}$ and $2017^{(8)}$ Agricultural Censuses were collected and analyzed. The data were compiled from the IBGE Automatic Recovery System (SIDRA), a database of statistical tables, which include aggregated data (without identification of the informant) collected from the IBGE surveys. The digital collection was based on using a descriptor of interest (for instance, territorial level), after which the period of availability was selected (for instance, year 2017), followed by the desired variables (for instance, area of the pasture) and, finally, the data were transferred. In addition, portions of the data were compiled and procured by directly contacting IBGE through e-mail.

\section{Definition of the variables}

In this study, several variables were considered for in-depth analyses. The variables and respective units are described in table 1 . The values concerning the area were expressed in tenths of hectares, while those regarding the milk production were expressed in thousands of liters.

\section{Data analyses}

Data were grouped into tables and subjected to statistical analysis. Descriptive analyses were done and the states and macro-regions were compared with respect to the absolute frequency (observed value) and relative variations, in percentage. From the most recent data, the degree of association among the variables was tested, through an exploratory approach, applying the Pearson linear correlation test ${ }^{(9)}$. This approach reveals associations, without any dependence among the variables and relationships which, in light of the kind of the responses involved, permit the appreciation of dependence of one variable on the other ${ }^{(10)}$. The results produced are thus represented as a correlation coefficient $(r)$ and differences were considered when $\mathrm{P}<0.05$. Correlation coefficients were attributed as strong $(r>0.6)$, moderate $(0.6 \leq r \geq 0.4)$ or weak $(r<0.4)$. All the statistical analyses were done using MS Excel ${ }^{\circledR}$ software (Excel 2019, Microsoft Corp., Redmond, WA, USA), together with the Action Stat ${ }^{\circledR}$ extension, version 3.7 (Estatcamp São Carlos, SP, Brazil). 
Table 1. Description of the variables studied and respective units

\begin{tabular}{lc}
\hline \multicolumn{1}{c}{ Variable } & Unit \\
\hline Number of properties with cattle & Producers in million \\
Area of properties with cattle & Hectare \\
Pasture area & Hectare \\
Cattle herd & Heads \\
Stocking rate & Head/hectare \\
Number of dairy farms & Producers in million \\
Milked cows & Heads \\
Annual milk production & Liters in billion \\
Milk productivity per cow & Liters in billion \\
Area of the states & Square kilometers \\
\hline
\end{tabular}

\section{Results and Discussion}

According to the 2017 Census, 5.07 million agricultural establishments were registered in Brazil. In fact, 2.55 million of them (50.36\%) supported cattle. However, in the 2006 Census, 2.67 million agricultural establishments were registered, showing a reduction of $4.63 \%$. This drop was noticeable particularly in the South $(-18.09 \%)$ and Northeast $(-8.49 \%)$ parts of the country, with the leading states being Pernambuco $(-23.02 \%)$, Rio Grande do Sul (-20.67\%) and Paraná (19.65\%), respectively. The North and Midwest regions, on the other hand, increased by $16.70 \%$ and $12.59 \%$, respectively (Table 2 ). Some of the factors which may have been responsible for the decline in the number of establishments supporting cattle during the intercensal period are listed: (i) aging of the rural population connected with the youth becoming too discouraged to remain in the rural areas ${ }^{(11)}$; (ii) less access to public rural credit policies ${ }^{(12) ;}$; (iii) productive inefficiency of the family dairy producers ${ }^{(13)}$; (iv) long dry period experienced by the Northeast region, which resulted in desertification and therefore, farmer migration ${ }^{(14) ;}$ as well as (v) competition of the areas for soybean production in the South ${ }^{(15,16)}$.

Brazil is a continental country, whose territory extends across nearly 8.51 million square kilometers (851.08 million hectares) ${ }^{(17)}$. According to the 2017 Census $23.87 \%$ of this area (203.12 million hectares) included establishments involved in raising cattle. The 2006 Census, on the contrary, revealed 198.81 million hectares of total area supporting establishments with cattle, suggesting that through the years $2.16 \%$ expansion has occurred in terms of the size of the area. This rise was noted mostly in the North (22.68\%), with the states of Roraima (44.09\%), Acre (33.92\%) and Amazonas (31.84\%) in order of rank (Table 2). On the other hand, in the South and Central-West region, there was a decrease of $6.47 \%$ and $4.90 \%$, respectively. It is noteworthy, therefore, that despite the decline in the number of establishments with cattle, there was a corresponding increase in the area of the remaining establishments, in the trend 
of land concentration, similar to the observation in agriculture, due to the expansion of soybean, corn and sugarcane ${ }^{(18)}$. The wide variations in technical and economic indicators, as stated by other studies ${ }^{(19,20)}$, could be a reason for the ranchers to decide to abandon their activity and sell off their land.

Table 2. Absolute values and relative variations (\%) from 2006 to 2017 in the number and area of the properties with cattle in the federative units of Brazil

\begin{tabular}{|c|c|c|c|c|c|c|}
\hline \multirow[b]{2}{*}{ Federative Unit } & \multicolumn{3}{|c|}{ Number of properties } & \multicolumn{3}{|c|}{ Area of properties } \\
\hline & 2006 & 2017 & $\begin{array}{c}\text { Variation } \\
\%\end{array}$ & 2006 & 2017 & $\begin{array}{c}\text { Variation } \\
\%\end{array}$ \\
\hline Acre & 18,626 & 22,649 & 21.60 & $1,898,325$ & $2,542,280$ & 33.92 \\
\hline Alagoas & 45,135 & 42,3 & -6.28 & 849,604 & 777,407 & -8.50 \\
\hline Amapá & 661 & 684 & 3.48 & 187,355 & 243,721 & 30.09 \\
\hline Amazonas & 13,782 & 14,612 & 6.02 & $1,584,982$ & $2,089,695$ & 31.84 \\
\hline Bahia & 314,243 & 297,894 & -5.20 & $14,392,599$ & $14,394,466$ & 0.01 \\
\hline Ceará & 124,456 & 114,714 & -7.83 & $3,970,588$ & $3,854,072$ & -2.93 \\
\hline Distrito Federal & 1,597 & 1,468 & -8.08 & 74,399 & 66,642 & -10.43 \\
\hline Espírito Santo & 30,935 & 33,128 & 7.09 & $1,049,378$ & $1,363,773$ & 29.96 \\
\hline Goiás & 111,693 & 126,1 & 12.90 & $19,190,475$ & $18,302,550$ & -4.63 \\
\hline Maranhão & 93,263 & 91,296 & -2.11 & $7,145,328$ & $7,517,452$ & 5.21 \\
\hline Mato Grosso & 82,558 & 92,723 & 12.31 & $33,389,648$ & $33,233,175$ & -0.47 \\
\hline Mato Grosso do Sul & 48,601 & 54,931 & 13.02 & $26,322,424$ & $23,501,628$ & -10.72 \\
\hline Minas Gerais & 354,062 & 385,488 & 8.88 & $20,142,257$ & $23,076,599$ & 14.57 \\
\hline Pará & 83,688 & 97,769 & 16.83 & $15,200,265$ & $19,546,348$ & 28.59 \\
\hline Paraíba & 92,024 & 82,761 & -10.07 & $2,169,735$ & $2,068,301$ & -4.67 \\
\hline Paraná & 211,936 & 170,296 & -19.65 & $5,164,513$ & $4,391,786$ & -14.96 \\
\hline Pernambuco & 140,226 & 107,939 & -23.02 & $2,198,318$ & $1,924,717$ & -12.45 \\
\hline Piauí & 75,469 & 70,48 & -6.61 & $3,887,725$ & $3,414,162$ & -12.18 \\
\hline Rio de Janeiro & 30,464 & 32,273 & 5.94 & $1,438,494$ & $1,775,018$ & 23.39 \\
\hline Rio Grande do Norte & 47,48 & 39,15 & -17.54 & $1,841,549$ & $1,783,325$ & -3.16 \\
\hline Rio Grande do Sul & 329,901 & 261,717 & -20.67 & $8,619,954$ & $7,941,435$ & -7.87 \\
\hline Rondônia & 63,273 & 73,129 & 15.58 & $6,678,968$ & $7,867,308$ & 17.79 \\
\hline Roraima & 4,732 & 6,903 & 45.88 & $1,113,021$ & $1,603,742$ & 44.09 \\
\hline Santa Catarina & 147,338 & 132,522 & -10.06 & $2,035,505$ & $2,420,024$ & 18.89 \\
\hline São Paulo & 128,238 & 107,255 & -16.36 & $7,133,257$ & $5,135,376$ & -28.01 \\
\hline Sergipe & 40,663 & 43,783 & 7.67 & 944,236 & 962,37 & 1.92 \\
\hline Tocantins & 43,348 & 50,451 & 16.39 & $10,190,508$ & $11,318,784$ & 11.07 \\
\hline Brazil & $2,678,392$ & $2,554,415$ & -4.63 & $198,813,414$ & $203,116,151$ & 2.16 \\
\hline
\end{tabular}

Source: IBGE (2006; 2017).

The principal food source for beef cattle production in Brazil, is pasture. Over the years, the pasture area showed a slight decrease. In 2017, a value of 159.5 million hectares was reported, $0.34 \%$ lower than in the earlier survey. The Northeast region revealed the 
highest decline in pasture area (-10.03\%), particularly in the states of Paraíba (-35.42\%) and Rio Grande do Norte (-21.37\%), as shown in Table 3. The reason for this decrease was the migration of farmers to other activities in the wake of droughts that hit this region during the intercensal period ${ }^{(14)}$. Likewise, the state of São Paulo also recorded a considerable decrease in the area of pastureland (-31.57\%), as a direct outcome of the land value, apart from the rise in demand across the world for biofuels and an expansion in the sugarcane production ${ }^{(18)}$, all of which affected the replacement of land use in the state.

Table 3. Absolute values and relative variations (\%) from 2006 to 2017 in the pasture area and cattle herd in the federative units of Brazil

\begin{tabular}{|c|c|c|c|c|c|c|}
\hline \multirow{2}{*}{ Federative Unit } & \multicolumn{3}{|c|}{ Pasture area } & \multicolumn{3}{|c|}{ Cattle herd } \\
\hline & 2006 & 2017 & $\begin{array}{c}\text { Variation } \\
\%\end{array}$ & 2006 & 2017 & $\begin{array}{c}\text { Variation } \\
\%\end{array}$ \\
\hline Acre & $1,051,319$ & $1,474,337$ & 40.24 & $1,736,100$ & $2,139,795$ & 23.25 \\
\hline Alagoas & 873,764 & 817,206 & -6.47 & 919,865 & 786,018 & -14.55 \\
\hline Amapá & 267,063 & 449,634 & 68.36 & 78,815 & 36,481 & -53.71 \\
\hline Amazonas & 820,702 & $1,141,768$ & 39.12 & $1,170,638$ & $1,252,835$ & 7.02 \\
\hline Bahia & $12,863,094$ & $11,831,006$ & -8.02 & $10,229,459$ & $8,177,761$ & -20.06 \\
\hline Ceará & $2,614,984$ & $2,368,980$ & -9.41 & $2,162,843$ & $1,892,771$ & -12.49 \\
\hline Distrito Federal & 79,796 & 62,108 & -22.17 & 81,441 & 62,91 & -22.75 \\
\hline Espírito Santo & $1,341,585$ & $1,473,072$ & 9.80 & $1,791,501$ & $1,650,374$ & -7.88 \\
\hline Goiás & $15,838,320$ & $14,991,172$ & -5.35 & $18,234,548$ & $17,292,288$ & -5.17 \\
\hline Maranhão & $5,754,670$ & $5,706,338$ & -0.84 & $5,812,164$ & $5,419,044$ & -6.76 \\
\hline Mato Grosso & $22,062,659$ & $23,011,251$ & 4.30 & $20,666,147$ & $24,309,475$ & 17.63 \\
\hline Mato Grosso do Sul & $21,055,122$ & $18,439,834$ & -12.42 & $20,634,817$ & $19,485,201$ & -5.57 \\
\hline Minas Gerais & $18,217,879$ & $19,371,750$ & 6.33 & $20,332,335$ & $19,575,839$ & -3.72 \\
\hline Pará & $11,071,104$ & $14,523,938$ & 31.19 & $13,933,883$ & $14,349,553$ & 2.98 \\
\hline Paraíba & $1,680,747$ & $1,085,344$ & -35.42 & $1,354,457$ & $1,050,612$ & -22.43 \\
\hline Paraná & $4,733,069$ & $4,016,635$ & -15.14 & $9,118,107$ & $8,397,219$ & -7.91 \\
\hline Pernambuco & $1,975,367$ & $1,768,999$ & -10.45 & $1,880,432$ & $1,284,796$ & -31.68 \\
\hline Piauí & $2,690,560$ & $2,131,808$ & -20.77 & $1,667,456$ & $1,427,467$ & -14.39 \\
\hline Rio de Janeiro & $1,290,362$ & $1,562,220$ & 21.07 & $1,924,217$ & $1,982,295$ & 3.02 \\
\hline Rio Grande do Norte & $1,203,399$ & 946,23 & -21.37 & 907,185 & 758,453 & -16.39 \\
\hline Rio Grande do Sul & $9,244,936$ & $9,176,761$ & -0.74 & $11,334,510$ & $11,456,896$ & 1.08 \\
\hline Rondônia & $4,845,185$ & $6,089,262$ & 25.68 & $8,542,726$ & $9,827,017$ & 15.03 \\
\hline Roraima & 724,175 & $1,114,772$ & 53.94 & 536,396 & 681,061 & 26.97 \\
\hline Santa Catarina & $1,707,633$ & $1,837,195$ & 7.59 & $3,126,002$ & $3,726,238$ & 19.20 \\
\hline São Paulo & $6,976,239$ & $4,773,687$ & -31.57 & $10,506,430$ & $8,331,874$ & -20.70 \\
\hline Sergipe & 945,207 & 877,693 & -7.14 & 899,298 & 887,354 & -1.33 \\
\hline Tocantins & $8,113,119$ & $8,454,545$ & 4.21 & $6,565,729$ & $6,477,537$ & -1.34 \\
\hline Brazil & $160,042,062$ & $159,497,547$ & -0.34 & $176,147,501$ & $172,719,164$ & -1.95 \\
\hline
\end{tabular}

Source: IBGE (2006; 2017). 
The North was the only region that increased in pasture area (23.63\%), particularly the states of Amapá (68.36\%), Roraima (53.94\%) and Acre (40.24\%; see Table 3), as seen by the advancement of the agricultural boundary in the Legal Amazon, influenced by the availability of credit and animal health protocols in this area ${ }^{(21)}$. A strong correlation ( $P$ $<0.05 ; r=0.99$ ) was observed between the pasture area and size of the rural establishments; however, only moderate correlation was identified $(P<0.05 ; r=0.50)$ between the pasture area and territorial expanse of the states (Table 4). Although no significant changes are noticeable in the pasture regions of Brazil, the productivity in these areas has escalated. While a decline was noted in the native pastures, $10 \%$ growth was observed in the cultivated or artificial pastures, the reason being deeper knowledge of the soil-plant-animal relationships(22), besides the implementation of pertinent technologies to intensify pasture utilization(23-26), an outcome of the committed studies done by research institutes and universities ${ }^{(27)}$.

Table 4. Linear correlation coefficients of the variables studied in 2017

\begin{tabular}{|c|c|c|c|c|c|c|c|c|c|c|}
\hline Paramete & ROP & AR & PAST & $\mathrm{CH}$ & SR & DPROP & MC & AMP & PRODC & ARS \\
\hline \multirow{2}{*}{ PROP } & \multirow{2}{*}{1} & $r=0.4 !$ & $r=0.53$ & $r=0.52$ & \multirow{2}{*}{ NS } & $r=0.97$ & $r=0.86$ & $r=0.83$ & $r=0.49$ & \multirow{2}{*}{ NS } \\
\hline & & $P=0.0$ & $2 P<0.01$ & $P=0.01$ & & $P<0.01$ & $P<0.01$ & $P<0.01$ & $P=0.01$ & \\
\hline \multirow{2}{*}{ AR } & & \multirow{2}{*}{1} & $r=0.99$ & $r=0.95$ & \multirow{2}{*}{ NS } & $r=0.42$ & $r=0.50$ & $r=0.38$ & \multirow{2}{*}{ NS } & $r=0.52$ \\
\hline & & & $P<0.01$ & $P<0.01$ & & $P=0.03$ & $P=0.01$ & $P=0.05$ & & $P=0.01$ \\
\hline \multirow{2}{*}{ PAST } & & & & $r=0.97$ & \multirow{2}{*}{ NS } & $r=0.51$ & $r=0.57$ & $r=0.47$ & \multirow{2}{*}{ NS } & $r=0.50$ \\
\hline & & & 1 & $P<0.01$ & & $P=0.01$ & $P<0.01$ & $P=0.01$ & & $P=0.01$ \\
\hline \multirow{2}{*}{$\mathrm{CH}$} & & & & 1 & NS & $r=0.52$ & $r=0.60$ & $r=0.52$ & \multirow{2}{*}{ NS } & $r=0.45$ \\
\hline & & & & 1 & כוס & $P=0.01$ & $P<0.01$ & $P<0.01$ & & $P=0.02$ \\
\hline SR & & & & & 1 & NS & NS & NS & NS & NS \\
\hline \multirow{2}{*}{ DPROP } & & & & & & \multirow{2}{*}{1} & $r=0.92$ & $r=0.92$ & $r=0.55$ & \multirow{2}{*}{ NS } \\
\hline & & & & & & & $P<0.01$ & $P<0.01$ & $P<0.01$ & \\
\hline \multirow{2}{*}{ MC } & & & & & & & 1 & $r=0.97$ & $r=0.48$ & \multirow{2}{*}{ NS } \\
\hline & & & & & & & 1 & $P<0.01$ & $P=0.01$ & \\
\hline \multirow{2}{*}{ AMP } & & & & & & & & 1 & $r=0.63$ & \multirow{2}{*}{ NS } \\
\hline & & & & & & & & & $P<0.01$ & \\
\hline PRODC & & & & & & & & & 1 & NS \\
\hline ARS & & & & & & & & & & 1 \\
\hline
\end{tabular}

PROP $=$ Number of properties with cattle; $\mathrm{AR}=$ Area of properties with cattle; PAST = Pasture area; $\mathrm{CH}=$ Cattle herd; $S R=$ Stocking rate; DPROP = Number of dairy farms; $M C=$ Milked cows; $A M P=$ Annual milk production; $P R O D C=$ Milk productivity per cow; ARS $=$ Area of the states. NS $=$ Not significant $(P>0.05)$. 
According to the 2017 census data, the cattle herd in Brazil was 172.72 million heads. However, the Municipal Livestock Survey (PPM), conducted annually by the IBGE, reported the cattle herd in 2017 was 214.90 million heads ${ }^{(28)}$. This rather huge inconsistency is possibly because in both surveys different methods were followed. While in the PPM, the date of reference is December 31, the 2017 census in Brazil accounted for the bovine herd head present on September 30. As a substantial number of producers adopt the breeding season technique, aiming at scheduling the birth season with the time of the highest pasture availability ${ }^{(29)}$, it is probable that a percentage of the calves will arrive during the last quarter of the year and, therefore, not be included in the count as live animals. Apart from this, the Census data was collected employing the direct interview method, by interrogating those responsible for rural establishments; however, the data in the PPM are drawn as inference from consultation with indirect sources, also a likely reason for the variations.

On comparing the cattle herd mentioned in the 2017 Census with the one in 2006, a slight variation was observed (-1.95\%), in which the Northeast region showed a more substantial decrease (-16.06\%), particularly, the states of Pernambuco $(-31.68 \%)$ and Bahia (-20.06\%). In the lead was the state of Mato Grosso with a total herd number of 24.31 million heads (showing 17.63\% more than the 2006 Census), following the growth trend in beef herds seen since the 1990s for this region. However, in 2006, the herd in the Midwest region exceeded the population of the Northern area by more than $110 \%$. Eleven years later, only $66 \%$ difference was observed between these two regions. The high growth rate confirmed in the North region was due to the higher contribution from the states of Roraima (26.97\%), Acre (23.25\%) and Rondônia (15.03\%). This shift in the production geography can be explained by several factors, including the cheaper land price and the likelihood of production outflow via new ports and shipping routes, which were the elements of attraction. In addition, an increase in the competition for the production factors was evident in the traditional regions due to the advanced scale of agriculture ${ }^{(30)}$. It should be noted that additional pressures may appear in the future as the demand for grain rises, for instance in countries like China, and the maintenance of high prices in the global market ${ }^{(31)}$.

On comparing the data from 2006 and 2017, the pasture stocking rate showed a slight increase (1.64\%), rising from 0.91 to 0.92 head per hectare, respectively. This result was possibly caused by the different methodologies followed in the two census surveys, with the likelihood of underestimating the number of cattle in 2017. However, another inference could be that because of the lack of any significant change in the pasture area, the increase in the size of the beef herd according to the 2017 PPM was indicative of a higher stocking rate. Despite this, these indices are almost negligible compared to other studies where a sample of technologically more advanced farms was studied (1.50 head/hectare) ${ }^{(19)}$ or the productive potential of the production systems was based on, exclusively, the use of pastures (9.60 heads/hectare) ${ }^{(32)}$.

In 2017, Brazil recorded 1.18 million milk-producing establishments, $12.92 \%$ lower than in 2006, when 1.35 million milk-producing properties were reported (Table 5). Although several Brazilian producers have ceased to practice this occupation, this number is still below the annual disappearance rate in other countries where milk production is better consolidated and more productive than Brazil, like Germany (2.77\%), France (3.00\%), 
United Kingdom $(4.10 \%)^{(33)}$ and United States $(20.00 \%)^{(34)}$.

In fact, 15 federative units reported a drop in the number of milk-producing establishments. Rio Grande do Sul was the leading state, showing the most obvious decrease in the number of producers (-36.62\%). On the other hand, the North region revealed the highest growth, especially in the states of Amapá (222.92\%), Roraima (155.57\%) and Amazonas (93.67\%), suggesting a displacement of the border for new regions and their consolidation at great distances from the large consumer centers.

Table 5. Absolute values and relative variations (\%) between 2006 and 2017 in the number of properties with milk production and milked cows in the federative units of Brazil

\begin{tabular}{|c|c|c|c|c|c|c|}
\hline \multirow[b]{2}{*}{ Federative Unit } & \multicolumn{3}{|c|}{ Number of dairy farms } & \multicolumn{3}{|c|}{ Milked cows } \\
\hline & 2006 & 2017 & $\begin{array}{c}\text { Variation } \\
\%\end{array}$ & 2006 & 2017 & $\begin{array}{c}\text { Variation } \\
\%\end{array}$ \\
\hline Acre & 6,451 & 6,514 & 0.98 & 40,225 & 40,476 & 0.62 \\
\hline Alagoas & 18,386 & 14,219 & -22.66 & 110,368 & 81,599 & -26.07 \\
\hline Amapá & 48 & 155 & 222.92 & 950 & 1,455 & 53.16 \\
\hline Amazonas & 2,466 & 4,776 & 93.67 & 36,811 & 59,083 & 60.50 \\
\hline Bahia & 118,8 & 108,268 & -8.87 & 833,749 & 650,6 & -21.97 \\
\hline Ceará & 83,213 & 73,272 & -11.95 & 399,017 & 354,776 & -11.09 \\
\hline Distrito Federal & 1,148 & 921 & -19.77 & 10,071 & 7,83 & -22.25 \\
\hline Espírito Santo & 17,829 & 17,141 & -3.86 & 245,75 & 197,109 & -19.79 \\
\hline Goiás & 69,688 & 72,353 & 3.82 & $1,321,920$ & $1,086,239$ & -17.83 \\
\hline Maranhão & 16,537 & 17,156 & 3.74 & 184,878 & 159,447 & -13.76 \\
\hline Mato Grosso & 33,86 & 34,825 & 2.85 & 452,465 & 427,333 & -5.55 \\
\hline Mato Grosso do Sul & 24,1 & 24,087 & -0.05 & 302,109 & 224,175 & -25.80 \\
\hline Minas Gerais & 223,073 & 216,46 & -2.96 & $3,174,871$ & $2,965,954$ & -6.58 \\
\hline Pará & 27,551 & 35,363 & 28.35 & 452,628 & 487,597 & 7.73 \\
\hline Paraíba & 47,393 & 38,591 & -18.57 & 208,324 & 154,057 & -26.05 \\
\hline Paraná & 119,81 & 87,063 & -27.33 & 881,577 & 873,512 & -0.91 \\
\hline Pernambuco & 54,039 & 37,643 & -30.34 & 296,178 & 222,344 & -24.93 \\
\hline Piauí & 30,747 & 25,37 & -17.49 & 126,416 & 92,622 & -26.73 \\
\hline Rio de Janeiro & 15,032 & 16,578 & 10.28 & 283,541 & 254,287 & -10.32 \\
\hline Rio Grande do Norte & 24,358 & 22,111 & -9.22 & 142,614 & 114,339 & -19.83 \\
\hline Rio Grande do Sul & 204,92 & 129,877 & -36.62 & 982,008 & 922,639 & -6.05 \\
\hline Rondônia & 35,384 & 39,368 & 11.26 & 572,447 & 588,217 & 2.75 \\
\hline Roraima & 817 & 2,088 & 155.57 & 8,948 & 16,861 & 88.43 \\
\hline Santa Catarina & 89,043 & 71,051 & -20.21 & 580,228 & 689,615 & 18.85 \\
\hline São Paulo & 54,323 & 40,92 & -24.67 & 755,235 & 527,813 & -30.11 \\
\hline Sergipe & 16,562 & 17,627 & 6.43 & 109,928 & 108,197 & -1.57 \\
\hline Tocantins & 15,231 & 22,498 & 47.71 & 197,445 & 198,612 & 0.59 \\
\hline Brazil & $1,350,809$ & $1,176,295$ & -12.92 & $12,710,701$ & $11,506,788$ & -9.47 \\
\hline
\end{tabular}

Source: IBGE (2006; 2017). 
The data from the 2017 Census suggested that the large majority of producers continue to be small-scale, with $92.6 \%$ of them producing up to 200 liters of milk per day. On the other hand, the biggest producers have been grabbing the attention on the national scene. The group producing more than 200 liters per day almost doubled during this period, escalating from 44 thousand liters in 2006 to above 87 thousand in 2017, but still representing only $7 \%$ of the total (Figure 1 ).

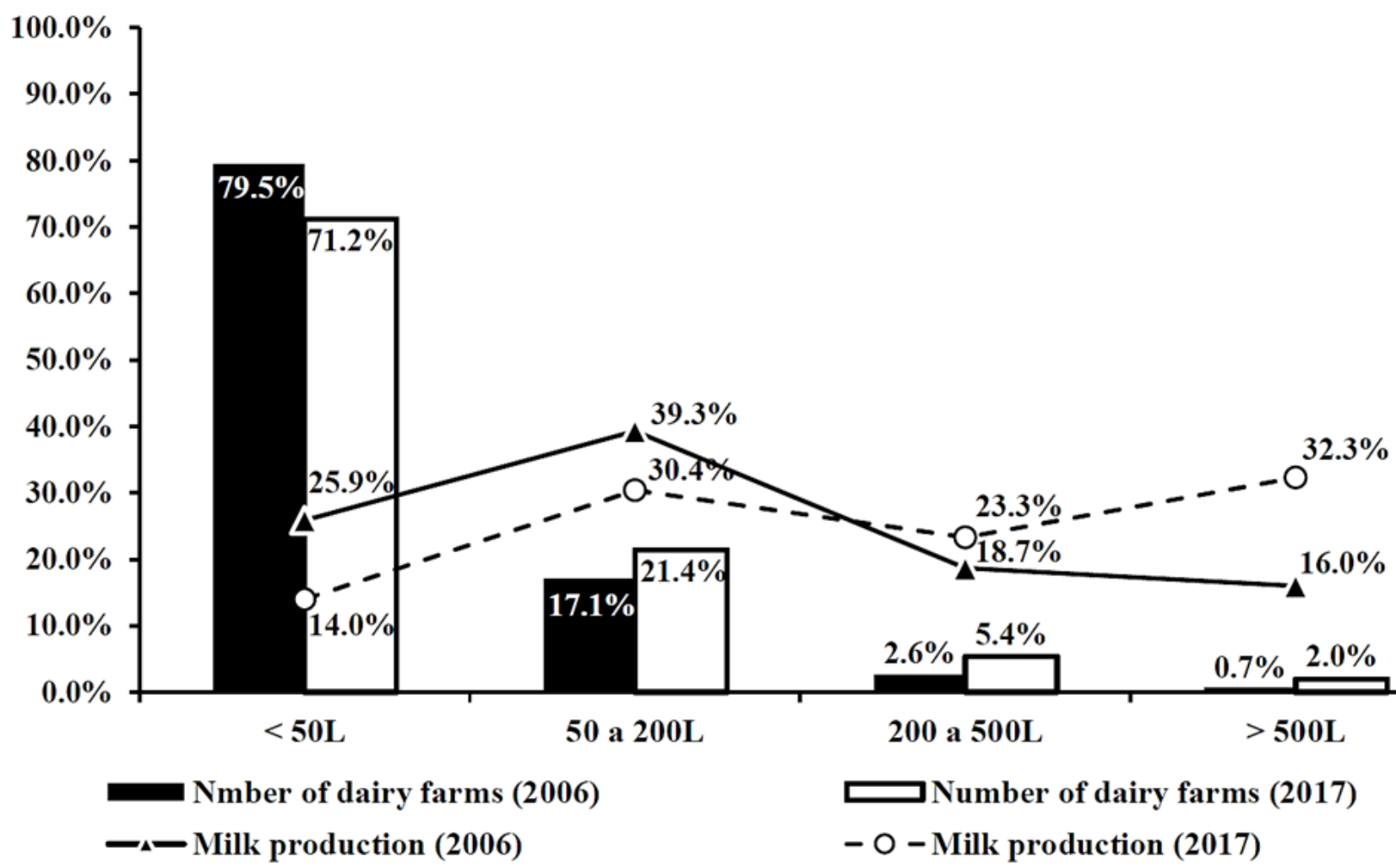

Figure 1. Number of dairy farms and total milk production separated based on production strata (liters of milk/day), in 2006 and 2017, in Brazil. Source: IBGE (2006; 2017).

According to the 2017 Census, 11.51 million cows were milked in Brazil. On comparison with the 2006 Census data, the number of cows milked showed a significant drop (9.47\%) (Table 5). This decline was observed in the regions of the Northeast (-19.63\%), Central-West $(-16.34 \%)$ and Southeast $(-11.53 \%)$, especially in the states of São Paulo (-30.11\%), Piauí (-26.73\%), Alagoas (-26.07\%) and Paraíba (26.05\%). In the South a slight rise $(1.72 \%)$ in the number of cows milked was seen, while in the North region a more expressive growth (6.33\%) was observed, particularly in the states of Roraima (88.43\%), Amazonas (60.50\%) and Amapá (53.16\%).

In general, land ownership is regarded as one of the limiting factors for the increase in milk production in the states ${ }^{(35)}$. However, in the current study no correlation was observed ( $P>0.05$; Table 4) between the number of milked cows and the territorial expanse of the states.

In 2017, the annual milk production surpassed the 30-billion-liter mark, a dramatic rise 
of $46.62 \%$ when compared to 2006. In the same year, the Southeast region of Brazil was still the leader in milk production $(11,124,177$ liters), followed by the South $(9,998,757$ liters), Midwest (3,873,942 liters), Northeast (3,253,115 liters) and North $(1,906,288$ liters) regions. The states recording the highest production were Minas Gerais $(8,746,559$ liters), followed by Rio Grande do Sul (3,928,863 liters), Paraná (3,258,876 liters) and Santa Catarina (2,811,018 liters), in the order of ranking. Between 2006 and 2017, all the federative units in Brazil showed an increase in production, with the exception of Paraíba (Table 6). Therefore, an increase in production was evident even in regions with no tradition in milk production, the reasons being the low land cost in some regions of the country, abundant yield of grains and lower prices of inputs, such as concentrated foods and labor. Furthermore, the annual milk production was observed to be more correlated with the number of cows milked $(P<0.05 ; r=0.97)$ and productivity per cow $(P<0.05 ; r=0.63)$, than with the area of rural establishments $(P<$ $0.05 ; r=0.38$; Table 4). This indicates that land availability is not the principal determinant for the volume of milk production in the Brazilian herds.

Despite the reduced number of milk-producing establishments and milked cows, the increase in the annual milk production is evident and can be explained by the rise in the productivity of dairy farming, which escalated from 1.6 thousand liters of milk per cow, per year, in 2006, to 2.6 thousand liters of milk, per cow, per year, in 2017. This implies a rise of $61.96 \%$, with more significance in the South $(72.98 \%)$ and Southeast $(62.31 \%$; Table) 6). A few states such as Minas Gerais, Rio Grande do Sul, Paraná and Santa Catarina, showed increased production during this time period, higher than the national average production. This may be attributed mainly to the increased professionalism in the management of the activity, improvement programs in animal genetics and more intense implementation of technologies with specialized technical assistance ${ }^{(36)}$, which contributed to a boost in the animal productivity, as well as to other production-related factors, like land, labor and capital. It should be noted, however, that higher rates were observed in a sample of 159 more 'technified' farms from Minas Gerais (3,383 liters/cow/year) ${ }^{(20)}$ or in 11,346 farms from New Zealand, in the temperate pastures $\left(3,567\right.$ liters/cow/year) ${ }^{(37)}$. This suggests the opportunity for gains in productive efficiency and greater competitiveness of the national dairy product in the international market.

The Agricultural Census reflects production-related information, as well as facilitates tracing the profiles of the producers. In terms of age group, an aging trend was observed among the ranchers. Between 2006 and 2017, the producers aged 65 years or older increased from $20.15 \%$ to $26.34 \%$. Similarly, the 55 to 65 years age group showed a rise from $21.37 \%$ in 2006 to $24.30 \%$ in 2017. By contrast, the share of younger producers in the 25 to 35 years age group decreased from $11.50 \%$ in 2006 to $7.55 \%$ in 2017; and, interestingly, participants below 25 years of age, also showed a decline from $2.41 \%$ in 2006 to $1.41 \%$ in 2017 . One of the likely reasons for this trend is the increased life expectancy of the Brazilian population and the resultant postponement of exit at the end of the job career(38), associated with the issues with succession from rural properties, and rural exodus by the youngsters ${ }^{(11)}$. It is suggested that the ranchers older in age may possibly negatively influence the adoption of technological innovations ${ }^{(39)}$ and explain the deficiency of technical guidance observed (in 2006, technical assistance was given to $25.19 \%$ of the properties with cattle versus $19.41 \%$ of 
the properties in 2017), with non-negligible effects on the productive and economic outcomes of the activity $(40,41)$. In this context, the technical assistance programs promoted by the government play a significant part in contributing to the dissemination of high-quality technical knowledge, and as a driving force for rural development.

Table 6. Absolute values and relative variations (\%) from 2006 to 2017 of annual milk production and milk yield per cow per year in the federative units of Brazil

\begin{tabular}{|c|c|c|c|c|c|c|}
\hline \multirow[b]{2}{*}{ Federative Unit } & \multicolumn{3}{|c|}{ Annual milk production } & \multicolumn{3}{|c|}{ Milk productivity per cow } \\
\hline & 2006 & 2017 & $\begin{array}{c}\text { Variation } \\
\%\end{array}$ & 2006 & 2017 & $\begin{array}{c}\text { Variation } \\
\%\end{array}$ \\
\hline Acre & 29,622 & 38,16 & 28.82 & 736 & 943 & 28.02 \\
\hline Alagoas & 176,588 & 188,628 & 6.82 & 1,6 & 2,312 & 44.48 \\
\hline Amapá & 1,07 & 1,507 & 40.84 & 1,126 & 1,036 & -8.04 \\
\hline Amazonas & 32,672 & 64,514 & 97.46 & 888 & 1,092 & 23.02 \\
\hline Bahia & 786,891 & 936,987 & 19.07 & 944 & 1,44 & 52.59 \\
\hline Ceará & 459,331 & 606,764 & 32.10 & 1,151 & 1,71 & 48.57 \\
\hline Distrito Federal & 18,079 & 19,933 & 10.25 & 1,795 & 2,546 & 41.81 \\
\hline Espírito Santo & 323,573 & 400,433 & 23.75 & 1,317 & 2,032 & 54.29 \\
\hline Goiás & $2,088,213$ & $2,670,391$ & 27.88 & 1,58 & 2,458 & 55.63 \\
\hline Maranhão & 174,525 & 188,304 & 7.90 & 944 & 1,181 & 25.10 \\
\hline Mato Grosso & 553,807 & 759,525 & 37.15 & 1,224 & 1,777 & 45.21 \\
\hline Mato Grosso do Sul & 383,88 & 424,092 & 10.48 & 1,271 & 1,892 & 48.88 \\
\hline Minas Gerais & $5,720,443$ & $8,746,559$ & 52.90 & 1,802 & 2,949 & 63.67 \\
\hline Pará & 476,332 & 646,799 & 35.79 & 1,052 & 1,327 & 26.05 \\
\hline Paraíba & 232,594 & 215,916 & -7.17 & 1,117 & 1,402 & 25.53 \\
\hline Paraná & $1,828,580$ & $3,258,876$ & 78.22 & 2,074 & 3,731 & 79.86 \\
\hline Pernambuco & 468,329 & 520,99 & 11.24 & 1,581 & 2,343 & 48.19 \\
\hline Piauí & 85,933 & 97,429 & 13.38 & 680 & 1,052 & 54.74 \\
\hline Rio de Janeiro & 432,355 & 511,895 & 18.40 & 1,525 & 2,013 & 32.02 \\
\hline Rio Grande do Norte & 193,085 & 228,161 & 18.17 & 1,354 & 1,995 & 47.39 \\
\hline Rio Grande do Sul & $2,457,964$ & $3,928,863$ & 59.84 & 2,503 & 4,258 & 70.13 \\
\hline Rondônia & 639,437 & 899,981 & 40.75 & 1,117 & 1,53 & 36.97 \\
\hline Roraima & 7,224 & 18,783 & 160.01 & 807 & 1,114 & 37.98 \\
\hline Santa Catarina & $1,396,222$ & $2,811,018$ & 101.33 & 2,406 & 4,076 & 69.40 \\
\hline São Paulo & $1,270,615$ & $1,465,290$ & 15.32 & 1,682 & 2,776 & 65.01 \\
\hline Sergipe & 148,409 & 269,936 & 81.89 & 1,35 & 2,495 & 84.80 \\
\hline Tocantins & 181,726 & 236,544 & 30.17 & 920 & 1,191 & 29.40 \\
\hline Brazil & $20,567,499$ & $30,156,278$ & 46.62 & 1,618 & 2,621 & 61.96 \\
\hline
\end{tabular}

Source: IBGE (2006; 2017).

With respect to gender, although men constitute the majority in the agricultural segment, the number of women participants in the livestock sector showed an increase (from 13.53\% in 2006 to $18.18 \%$ in 2017). Such inequality in female participation in this 
sector is not limited to Brazil(42), being more associated with small rural enterprises ${ }^{(43)}$. Despite the numerous vulnerabilities ${ }^{(44-45)}$, the valorization of women in livestock activity can be partially explained by the public policies aimed at the encouragement of women in this field ${ }^{(12)}$.

In this study, a few probable limitations are identifiable, such as the changes in methodology, reference period and criteria of categorization, adopted by the IBGE. In the most recent survey of the Agricultural Census, innovations in the methodology were included in order to unify the concepts and ensure maximum comparability of the results with those from other countries promoting similar surveys ${ }^{(46)}$. It is also noteworthy that, as cited above, the timing of the application of the two Agricultural Censuses corresponded to different periods. Therefore, in spite of the fact the results from the two surveys may provide valuable support for the investigation and reveal, in part, the dimension and complexity of the rural reality of Brazil, they are not strictly comparable. Additionally, the criteria for classifying dairy farms in Brazil indicate another likely limitation because the IBGE census methodology may include beef cattle farms which sell some surplus calf milk, not necessarily mirroring the reality of the farms in this country(20).

\section{Conclusions}

The Brazilian federative units showed several transformations in livestock farming from 2006 to 2017. The principal ones include the changes in the geography of production, particularly in the Northern part of the country; higher concentration and professionalization of the livestock activity; and a noteworthy rise in milk production, in almost every state, which is reflective of the improved productivity of the national herd, although continuing to be much lower than the average of specialized herds.

The information generated from this study contributes to a better characterization and strategic design in the dairy production chain for the policy makers, private sector, research institutes and the many different links and agents in this chain, in order to further elevate its protagonism in the international scenario.

\section{Conflict of interests}

The authors declare no conflict of interests.

\section{Acknowledgements}

The authors would like to thank Raquel Louise Canezim for helping with data collection and the anonymous reviewers for the corrections and suggestions made to the 
preliminary version of the manuscript.

\section{References}

1. Ferraz JB, Felício PE. Production systems - an example from Brazil. Meat Science. 2010; 84(2): 238-243.

2. Stock LA, Zoccal R, Carvalho GR, Siqueira KB. Competitividade do agronegócio do leite brasileiro. Embrapa Informação Tecnológica, 2011. 326p. Portuguese.

3. EMBRAPA. O futuro da cadeia produtiva da carne bovina brasileira: uma visão para 2040. Campo Grande, MS: Embrapa Gado de Corte, 2020. 136p. Portuguese.

4. Vilela D, Resende JC, Leite JB, Alves E. A evolução do leite no Brasil em cinco décadas. Revista de Política Agrícola. 2017; 26(1): 5-24.

5. Estanislau P, Goebel MA, Staduto JAR, Kreter AC. Spatial distribution of agricultural farms led by women in Brazil. Revista de Economia e Sociologia Rural. 2021; 59(e222800).

6. Gasques JG, Bastos ET, Valdes C, Bacchi MRP. Total factor productivity in Brazilian agriculture. In: Fuglie KO, Wang SL, Ball VE (Org.). Productivity growth in agriculture: an international perspective. Oxfordshire: CAB International, 2012.

7. IBGE - Instituto Brasileiro de Geografia e Estatística. Censo Agropecuário 2006. Available from: https:/ Isidra.ibge.gov.br/pesquisa/censo-agropecuario/censo-agropecuario-2006/segunda-apuracao. Portuguese.

8. IBGE - Instituto Brasileiro de Geografia e Estatística. Censo Agropecuário 2017. Available from: https:/ Isidra.ibge.gov.br/pesquisa/censo-agropecuario/censo-agropecuario-2017. Portuguese.

9. Sampaio IBM. Estatística aplicada à experimentação animal. 3. ed. Belo Horizonte: Fundação de Estudo e Pesquisa em Medicina Veterinária e Zootecnia, 2010. 264p. Portuguese.

10. Naghettini M, Pinto ÉJA. Hidrologia estatística. Belo Horizonte: CPRM, 2007. 552p. Portuguese.

11. Oliveira MF, Mendes L, Vasconcelos ACVH. Desafios à permanência do jovem no meio rural: um estudo de casos em Piracicaba-SP e Uberlândia-MG. Revista de Economia e Sociologia Rural. 2021; 59(2): e222727.

12. Scheuer JM. Dinâmica da agricultura brasileira em 2006-2017. Revista Política Agrícola. 2019; 28(3): 131-147.

13. Gonçalves RML, Vieira WC, Lima JE, Gomes ST. Analysis of technical efficiency of milk producing farms in Minas Gerais. Economia Aplicada. 2008; 12(2): 321-335.

14. Azevedo SCD, Cardim GP, Puga F, Singh RP, Silva EA. Analysis of the 2012-2016 drought in the northeast Brazil and its impacts on the Sobradinho water reservoir. Remote Sensing Letters. 2018; 9(5): 438-446.

15. Oliveira TE, Freitas DS, Gianezini M, Ruviaro CF, Zago D, Mércio TZ, Dias EA, Lampert VN, Barcellos JOJ. Agricultural land use change in the Brazilian Pampa Biome: The reduction of natural grasslands. Land Use Policy. 2017; 63(1): 394-400.

16. Moreira JG, Conterato MA, Matte A. Transformações produtivas e mudanças no uso da terra no pampa brasileiro: influências no avanço da soja na bovinocultura de corte. Revista Campo-Território. 2019; 14(33): 179-207.

17. IBGE - Instituto Brasileiro de Geografia e Estatística. Brasil em síntese. 2021. Available from: https:// brasilemsintese.ibge.gov.br/territorio.html. Portuguese.

18. Novo ALM, Jansen K, Slingerland M, Giller K. Biofuel, dairy production and beef in Brazil: competing claims on land use in São Paulo state. The Journal of Peasant Studies. 2010; 37(4): 769-792.

19. FAEMG - Federação da Agricultura e Pecuária do Estado de Minas Gerais. Diagnóstico da pecuária bovina de corte em Minas Gerais. 2016. 147p. Portuguese.

20. Pereira MN, Resende JC, Pereira RAN, Silva HCM. Indicadores de desempenho de fazendas leiteiras de Minas Gerais. Arquivos Brasileiros de Medicina Veterinária e Zootecnia. 2016; 68(4): 1033-1042.

21. Freitas Junior AM, Barros PHB. A expansão pecuária para a Amazônia legal: externalidades espaciais, acesso ao mercado de crédito e intensificação do sistema produtivo. Nova Economia. 2021; 31(1): 


\section{3-333.}

22. Silva SC, Nascimento Junior D. Avanços na pesquisa com plantas forrageiras tropicais em pastagens: características morfofisiológicas e manejo do pastejo. Revista Brasileira Zootecnia. 2007; 36(Suplemento Especial): 121-138.

23. Delevatti LM, Cardoso AS, Barbero RP, Leite RG, Romanzini EP, Ruggieri AC, Reis RA. Effect of nitrogen application rate on yield, forage quality, and animal performance in a tropical pasture. Scientific Reports. 2019; 9(7596).

24. Gil J, Siebold M, Berger T. Adoption and development of integrated crop-livestock-forestry systems in Mato Grosso, Brazil. Agriculture, Ecosystems and Environment. 2015; 199(1): 394-406.

25. Mandarino RA, Barbosa FA, Lopes LB, Telles V, Florence EAS, Bicalho FL. Evaluation of good agricultural practices and sustaintability indicators in livestock systems under tropical conditions. Agricultural Systems. 2019; 174: 32-38.

26. Vieira BR, Azenha MV, Casagrande DR, Costa DFA, Ruggieri AC, Berchielli TT, Reis RA. Ingestive behavior of supplemented Nellore heifers grazing palisadegrass pastures managed with different sward heights. Animal Science Journal; 88(4): 696-704.

27. Lobato JFP, Freitas AK, Devincenzi T, Cardoso LL, Tarouco JU, Vieira RM, Dillenburg DR, Castro I. Brazilian beef produced on pastures: Sustainable and healthy. Meat Science. 2014; 98(3): 336-345.

28. IBGE - Instituto Brasileiro de Geografia e Estatística. Pesquisa Pecuária Municipal. Rio de Janeiro, RJ, 2018. Available from: https://www.ibge.gov.br/estatisticas/economicas/agricultura-e-pecuaria/9107producao-da-pecuaria-municipal.html. English.

29. Castro FC, Fernandes H, Leal CLV. Sistemas de manejo para maximização da eficiência reprodutiva em bovinos de corte nos trópicos. Veterinária e Zootecnia. 2018; 25(1): 41-60.

30. Leite JLB, Stock LA, Siqueira KB, Zoccal R. Dinâmica da pecuária leiteira no Brasil: evolução de características das propriedades. Panorama do Leite. 2015; 7(82): 12-15.

31. EMBRAPA. Visão 2030: o futuro da agricultura brasileira. Brasília, DF: Embrapa, 2018. 212p. Portuguese.

32. Herling VR, Pedreira CGS, Luz PHC, Braga GJ, Marchesin WA, Macedo FB, Lima CG. Performance and productivity of Nellore steers on rotationally stocked palisadegrass (Brachiaria brizantha) pastures in response to herbage allowance. The Journal of Agricultural Science. 2011; 149(6): 761-768.

33. EUROSTAT. Annual enterprise statistics for special aggregates of activities. 2018. Available from: https://ec.europa.eu/eurostat/data/database. English.

34. USDA NASS. 2017 Census of Agriculture. 2019. Available from: https://www.nass.usda.gov/ Publications/AgCensus/2017/Full Report/Volume 1, Chapter 1 US/usv1.pdf. English.

35. Neiva ACGR, Neiva JNM. Do campus para o campo: tecnologias para a produção de leite. Fortaleza: Expressão Gráfica e Editora, 2006. 320p. Portuguese.

36. Beber CL, Carpio AFR, Almadani MI, Theuvsen L. Dairy supply chain in Southern Brazil: barriers to competitiveness. International Food and Agribusiness Management Review. 2019; 22(5): 651-673.

37. NEW ZELAND DAIRY. National dairy statistics 2007-2008. Available from: http://www.dairynz.co.nz/ file/fileid/11947. English.

38. BRASIL. Síntese de indicadores sociais: uma análise das condições de vida da população brasileira: 2015. IBGE, Coordenação de população e indicadores sociais. Rio de Janeiro: IBGE, 2015. Available from: http://biblioteca.ibge.gov.br. Portuguese.

39. Souza Filho HM, Buainain AM, Silveira JMFJ, Vinholis MMB. Condicionantes da adoção de inovações tecnológicas na agricultura. Cadernos de Ciência \& Tecnologia. 2011; 28(1): 223-255.

40. Gomes AP, Ervilha GT, Freitas LF, Nascif C. Assistência técnica, eficiência e rentabilidade na produção de leite. Revista de Política Agrícola. 2018; 27(2): 79-94.

41. Rocha Junior A, Silva RO, Peterle Neto W, Rodrigues CT. Efeito da utilização de assistência técnica sobre a renda de produtores familiares do Brasil no ano de 2014. Revista de Economia e Sociologia Rural. 2020; 58(2): 1-16.

42. Hoppe RA, Korb P. Characteristics of women farm operators and their farms. Economic Information Bulletin, n. 111. Washington, DC. 2013. 51p. 
43. Schmidt C, Goetz SJ, Tian Z. Female farmers in the United States: Research needs and policy questions. Food Policy. 2021; In Press.

44. CEPEA - Centro de Estudos Avançados em Economia Aplicada. Mulheres no agronegócio. Piracicaba, v. 2, edição especial, 2019. Portuguese.

45. Spanevello RM, Oliveira SV, Lago A, Christofari LF, Andreatta T, Chechi LA. O trabalho das mulheres na pecuária leiteira: análise em contextos de produção modernos, tradicionais e em transição no Rio Grande do Sul (Brasil). DRd - Desenvolvimento Regional em debate. 2020; 10: 655-676.

46. Teixeira G. O Censo Agropecuário 2017, Revista NECAT. 2019; 8(16): 8-39. 